\title{
Knowledge Regarding Self-Administration of Insulin Among the Diabetic Patient Attending the Diabetic Clinic of Tertiary Care Center of Eastern Nepal
}

\author{
Shrestha $\mathrm{D}^{1}$, Basnet $\mathrm{S}^{1}$, Parajuli $\mathrm{P}^{1}$, Baral $\mathrm{D}^{2}$, Badhu $\mathrm{A}^{3}$ \\ ${ }^{1}$ Department of Medical Surgical Nursing, College of Nursing, B.P. Koirala Institute of Health Sciences, \\ ${ }^{2}$ School of Public Health, B.P. Koirala Institute of Health Sciences, ${ }^{3}$ Chief of College of Nursing, B.P. \\ Koirala Institute of Health Sciences.
}

\begin{abstract}
Background: Diabetes Mellitus(DM), usually called diabetes or sugar is the condition that occurs when one's body does not produced enough insulin or body is unable to use normal amount of insulin properly. Objectives: The objectives of this study were to assess the Knowledge and Practice Regarding Selfadministration of insulin among the diabetic patient attending the diabetic clinic of BPKIHS, to find out the association between knowledge and Practice with their selected socio-demographic variables and to find out association between knowledge and practice regarding self-administration of insulin.

Methods: A descriptive cross-sectional study design was used to conduct the study among the Diabetic patient attending the diabetic clinic of BPKIHS. Data were collected using the self structured questionnaire.

Results: The findings revealed that mean knowledge of the participants was $57.55 \%$ and practice was $73.98 \%$. Among them $54 \%(27)$ of participants has inadequate knowledge, remaining $46 \%(23)$ has adequate knowledge. Similarly, 48\%(24) of participants has inadequate practice, and remaining 52\%(26) has adequate practice. There was significant association of educational status with knowledge regarding self administration of insulin with pvalue 0.03 and there was significant association with occupation with knowledge regarding self administration of insulin with pvalue 0.047 . There was also association between knowledge and practice regarding self administration of insulin with pvalue 0.049

Conclusion: Educational and ccupational status has influence on knowledge regarding self administration of insulin. Thus it is essential to focus on improving the patient's knowledge on the related topic so that the participants can enhance their practice as well. Diabetes \& Insulin Self Administration education must be imparted by physicians by counselling patients at each follow up visit.
\end{abstract}

Key Words: Knowledge, Practice, Diabetes Mellitus and Self administration of insulin

\section{Introduction:}

Diabetes is a serious, chronic disease that occurs either when the pancreas does not produce enough insulin (a hormone that regulates blood glucose), or when the body cannot effect ively use the insulin it produces $^{1}$.

Lifestyle modification i.e. nutritional management, exercise, monitoring blood glucose level, education, etc. plays a vital role in the management of diabetes ${ }^{2}$.
With the advancement in medical science and technology, pharmacological therapy i.e. oral antidiabetic agents and insulin therapy has an important role in maintaining the blood glucose level among diabetic patients ${ }^{1}$. Successful self management in Diabetes helps the patient feel better. Education is an important aspect of self-management, teaching the client on self administration of insulin helps the patient helps to build self confidence and pride of contribution in their management ${ }^{3}$. Insulin therapy 
has been proven to be effective in controlling blood glucose level among the diabetic patients. Insulin is used to treat a number of diseases including diabetes and its acute complications such as diabetic ketoacidosis and hyperosmolar hyperglycemic states. It is also used along with glucose to treat high blood potassium levels ${ }^{1}$.

The objectives of this study were to assess the Knowledge and Practice Regarding Selfadministration of insulin among the diabetic patient attending the diabetic clinic of BPKIHS, to find out the association between knowledge and Practice with their selected socio-demographic variables and to find out association between knowledge and practice regarding self-administration of insulin.

\section{Methods}

This study was descriptive cross-sectional study design done in Diabetic Clinic of Medical OPD of BPKIHS, Dharan. Patient who are clinically diagnosed by certified physician with diabetes mellitus and are under self-administration of insulin were taken for the study. This study considers $95 \%$ confidence interval and 80.5 power to estimate the sample size. For this purpose, study considers $52.5 \%$ of prevalence of knowledge regarding selfadministration of insulin among the diabetic patient. Using The formula the sample were 50. Non Probability Purposive Sampling technique was used.

The Exclusion Criteria Patient who were unable to communicate and patients who takes assistance from others in administration of insulin.

A pre-tested self prepared interview questionnaire was developed on the basis of objectives, review of literature and the opinion from the experts to assess the Knowledge and Practice Regarding SelfAdministration of Insulin among the Diabetic Patients Attending the Diabetic Clinic of BPKIHS. This tools were used to collect data from each study subject in the study settings. It was divided into 2 parts.

Part I consist socio-demographic data of the study subject like address, age, sex, marital status, religion, educational status, occupation, economical status, duration of illness and family history. Part II consist of self structured interview questionnaire related to Knowledge Regarding Self-Administration of Insulin among the Diabetic Patient Attending Diabetic Clinic of BPKIHS. It consists total of 23 questions. Section C: It consist of self structured interview questionnaire related to Practice Regarding Self-Administration of Insulin Among The Diabetic Patient Attending Diabetic Clinic Of BPKIHS. It consists total of 18 questions.

The written permission was obtained from the Institutional Review Committee of College Of Nursing. Informed consent was taken from the clients.

Data was entered in MS-Excel 2011 and converted into SPSS version 11.5 for statistical analysis. Descriptive Statistics such as Percentage, mean, median, interquartile range, and standard deviation was used for analyzing the data. Appropriate inferential statistics was used as per need. The findings were presented in the form of tables or graphs as applicable. 
Knowledge Regrading Self-Administration of Insulin

Jour of Diab and Endo Assoc of Nepal 2018; 2 (1): (9-16)

\section{Results:}

Table 1: Socio - Demographic Characteristics of The Participants $(n=50)$

\begin{tabular}{|c|c|c|c|}
\hline Characteristic & Category & No.of sample & Percentage \\
\hline \multirow[t]{4}{*}{ Age } & $<30$ years & 2 & 4.0 \\
\hline & $30-50$ years & 9 & 18.0 \\
\hline & $50-70$ years & 32 & 64.0 \\
\hline & $>70$ years & 7 & 14.0 \\
\hline \multicolumn{2}{|l|}{ Mean Age \pm SD (Min- Max) } & \multicolumn{2}{|c|}{$57.30 \pm 12.156(14-75)$} \\
\hline \multirow{2}{*}{ Sex } & Male & 29 & 58.0 \\
\hline & Female & 21 & 42.0 \\
\hline \multirow[t]{4}{*}{ Marital status } & Unmarried & 2 & 4.0 \\
\hline & Married & 44 & 88.0 \\
\hline & Divorced & 1 & 2.0 \\
\hline & Widow / Widower & 3 & 6.0 \\
\hline \multirow[t]{3}{*}{ Religion } & Hindu & 42 & 84.0 \\
\hline & Buddhist & 5 & 10.0 \\
\hline & Christian & 3 & 6.0 \\
\hline \multirow[t]{3}{*}{ Educational status } & Primary level & 29 & 58.0 \\
\hline & Secondary level & 14 & 28.0 \\
\hline & Higher secondary \& above & 7 & 14.0 \\
\hline \multirow[t]{5}{*}{ Occupational status } & Homemaker & 18 & 36.0 \\
\hline & Agriculture/ Labour & 7 & 14.0 \\
\hline & Business & 8 & 16.0 \\
\hline & Service & 7 & 14.0 \\
\hline & Others & 10 & 20.0 \\
\hline \multirow[t]{4}{*}{ Economical status } & $<10,000$ & 4 & 8.0 \\
\hline & $10,000-20,000$ & 22 & 44.0 \\
\hline & $20,000-30,000$ & 20 & 40.0 \\
\hline & $>30,000$ & 4 & 8.0 \\
\hline \multirow[t]{2}{*}{ Family h/o DM } & No & 37 & 74.0 \\
\hline & Yes & 13 & 26.0 \\
\hline \multirow[t]{2}{*}{ Relationship with diabetic person } & First degree relative & 12 & 92.3 \\
\hline & Second degree relative & 1 & 7.7 \\
\hline \multirow[t]{4}{*}{ Duration of DM } & $<1$ years & 3 & 6.0 \\
\hline & $1-10$ years & 16 & 32.0 \\
\hline & $10-20$ years & 23 & 46.0 \\
\hline & $>20$ years & 8 & 16.0 \\
\hline \multicolumn{2}{|l|}{ Mean Age \pm SD(Min-Max) } & \multicolumn{2}{|c|}{$11.172 \pm 8.6522(0.5-43.0)$} \\
\hline Characteristic & Category & No. of sample & Percentage \\
\hline \multirow[t]{3}{*}{ Duration of insulin } & 3 months-1 year & 24 & 48.0 \\
\hline & $1-5$ years & 17 & 34.0 \\
\hline & $>5$ years & 9 & 18.0 \\
\hline \multicolumn{2}{|l|}{ Mean Age \pm SD ( Min-Max) } & $2.964 \pm$ & $3752(0.3-21.0)$ \\
\hline \multirow[t]{3}{*}{ Device used } & Pen injector & 41 & 82.0 \\
\hline & Insulin syringe & 6 & 12.0 \\
\hline & Both & 3 & 6.0 \\
\hline \multirow[t]{2}{*}{ Information about DM } & Yes & 25 & 50.0 \\
\hline & No & 25 & 50.0 \\
\hline \multirow[t]{6}{*}{ means of information } & Mass media & 6 & 24.0 \\
\hline & Health personnel & 1 & 4.0 \\
\hline & Relatives & 12 & 48.0 \\
\hline & Mass media \& relatives & 2 & 8.0 \\
\hline & Health personnel \& realtive & 1 & 4.0 \\
\hline & $\begin{array}{l}\text { mass media, health personal \& } \\
\text { realtives }\end{array}$ & 3 & 12.0 \\
\hline
\end{tabular}


Table 2: Knowledge \& Practice Regarding Self Administration Of Insulin( $n=50)$

\begin{tabular}{|c|c|c|c|}
\hline Characteristics & Category & No.of sample & Percentage (\%) \\
\hline \multirow{2}{*}{ Knowledge } & Inadequate & 28 & 56 \\
\cline { 2 - 4 } & Adequate & 22 & 44 \\
\hline \multirow{2}{*}{ Practice } & Inadequate & 24 & 48 \\
\cline { 2 - 4 } & Adequate & 26 & 52 \\
\hline
\end{tabular}

Table 3: Knowledge Regarding Storage of Insulin $(n=50)$

\begin{tabular}{|l|c|c|c|c|}
\hline Storage of Insulin & \multicolumn{2}{|c|}{ Correct Responses } & \multicolumn{2}{c|}{ Incorrect response } \\
\hline Frequency & $\begin{array}{c}\text { Percentage } \\
(\%)\end{array}$ & Frequency & $\begin{array}{c}\text { Percentage } \\
(\%)\end{array}$ \\
\hline Appropriate place for storage of insulin at home & 45 & 90 & 5 & 10 \\
\hline Stomperature of refrigerator for Insulin & & & & \\
\hline Room Temperature for insulin storage & 25 & 50 & 25 & 50 \\
\hline Appropriate technique for insulin storage & 3 & 6 & 47 & 94 \\
\hline Rationale storing insulin in cool \& dry place & 24 & 48 & 26 & 52 \\
\hline Duration for the usage of single insulin vial & 49 & 38 & 31 & 62 \\
\hline Duration for the usage of single insulin syringe & 50 & 80 & 10 & 20 \\
\hline
\end{tabular}

The above table depicts that $90 \%$ of the participants had knowledge regarding the appropriate place for the storage of insulin. Only half of the participants i.e. 50\% had knowledge regarding the required temperature of the refrigerator for storage of insulin whereas only $6 \%$ of the participants knew about the required room temperature for the storage of insulin.

Table 4: Knowledge Regarding Techniques Of Insulin Administration( $n=50)$

\begin{tabular}{|c|c|c|c|c|}
\hline Techniques Of Insulin Administration & \multicolumn{2}{|c|}{ Correct Responses } & \multicolumn{2}{|c|}{ Incorrect response } \\
\hline & Frequency & Percentage $(\%)$ & Frequency & Percentage $(\%)$ \\
\hline Appropriate time for administration of insulin & 39 & 78 & 11 & 22 \\
\hline Rolling the vial of insulin in between hands before & & & & \\
\hline $\begin{array}{l}\text { administration } \\
\text { Sites of administration of insulin }\end{array}$ & 25 & 50 & 25 & 50 \\
\hline Abdomen & 47 & 94 & 3 & 6 \\
\hline Thigh & 45 & 90 & 5 & 10 \\
\hline Upper arm & 16 & 32 & 34 & 69 \\
\hline Buttocks & 12 & 24 & 38 & 76 \\
\hline $\begin{array}{l}\text { Insulin can be administered in the site of swelling/ } \\
\text { tenderness/scars/lipodystrophy }\end{array}$ & 50 & 100 & 0 & 0 \\
\hline $\begin{array}{l}\text { Technique to dry the alcohol wipe sites before } \\
\text { administration of insulin }\end{array}$ & 28 & 56 & 22 & 44 \\
\hline Correct angle for the administration of insulin & 23 & 46 & 27 & 54 \\
\hline $\begin{array}{l}\text { Distance to be considered for the rotation of insulin } \\
\text { administration }\end{array}$ & 20 & 40 & 30 & 60 \\
\hline Ways to reduce pain during insulin administration & 28 & 56 & 22 & 44 \\
\hline Rationale for the rotation of insulin administration site & & & & \\
\hline To reduce pain & 37 & 74 & 13 & 26 \\
\hline To prevent from lipodystrophy & 8 & 16 & 42 & 84 \\
\hline
\end{tabular}


Knowledge Regrading Self-Administration of Insulin

Jour of Diab and Endo Assoc of Nepal 2018; 2 (1):(9-16)

Table 5: Knowledge Regarding Complication of Insulin Therapy $(n=50)$

\begin{tabular}{|l|c|c|c|c|}
\hline Complication of Insulin Therapy & \multicolumn{2}{|c|}{ Correct Responses } & \multicolumn{2}{c|}{ Incorrect response } \\
\hline & Frequency & $\begin{array}{c}\text { Percentage } \\
(\%)\end{array}$ & Frequency & $\begin{array}{c}\text { Percentage } \\
(\%)\end{array}$ \\
\hline Complications of Insulin therapy & & & & \\
\hline Low Blood Sugar & 15 & 30 & 35 & 70 \\
\hline Lipodystrophy & 8 & 16 & 42 & 84 \\
\hline Insulin Allergy/Resistance & 7 & 14 & 43 & 86 \\
\hline
\end{tabular}

The above table depicts that only $30 \%$ of the participants had knowledge regarding low bloo sugar as a complication of insulin therapy followed by lipodystrophy $16 \%$ and insulin allergy/resistance $14 \%$.

Table 6: Practice Regarding Self Administration of Insulin ( $n=50)$

\begin{tabular}{|c|c|c|c|c|c|c|c|}
\hline \multirow[t]{2}{*}{ S.N } & \multirow[t]{2}{*}{ Insulin self administration technique } & \multicolumn{2}{|c|}{ Always } & \multicolumn{2}{|c|}{ Sometime } & \multicolumn{2}{|c|}{ Never } \\
\hline & & Frequency & $\begin{array}{c}\text { Percentage } \\
(\%)\end{array}$ & Frequency & $\begin{array}{c}\text { Percentage } \\
(\%)\end{array}$ & Frequency & $\begin{array}{c}\text { Percentage } \\
(\%)\end{array}$ \\
\hline 38. & Handwashing & 44 & 88 & 2 & 4 & 4 & 8 \\
\hline 39. & $\begin{array}{l}\text { Check the blood glucose level before and after } \\
\text { administration of insulin. }\end{array}$ & 3 & 6 & 22 & 44 & 25 & 50 \\
\hline 40. & Observe the insulin characteristics. & 48 & 96 & 1 & 1 & 1 & 1 \\
\hline 41. & Use insulin without shaking it. & 38 & 76 & 12 & 24 & 0 & 0 \\
\hline 42. & Check whether insulin device is broken/damaged. & 50 & 100 & 0 & 0 & 0 & 0 \\
\hline 43. & For Insulin Syringe & & & & & & \\
\hline a. & Wipe the rubber top of insulin with alcohol at $70 \%$. & 2 & 4 & 0 & 0 & 7 & 14 \\
\hline b. & Inject air into insulin bottle. & 2 & 4 & 0 & 0 & 7 & 14 \\
\hline c. & $\begin{array}{l}\text { Draw up the quantity of insulin necessary to } \\
\text { complete the prescribed dose. }\end{array}$ & 9 & 18 & 0 & 0 & 0 & 0 \\
\hline d. & Remove the bubble from syringe & 8 & 16 & 0 & 0 & 1 & 2 \\
\hline 44. & For Pen Injector & & & & & & \\
\hline a. & Clean the air from needle & 16 & 32 & 7 & 14 & 21 & 42 \\
\hline b. & Set up the dial at zero after removing air from needle. & 19 & 38 & 5 & 10 & 20 & 40 \\
\hline c. & Fix the unit/dose of insulin as prescribed. & 44 & 88 & 0 & 0 & 0 & 0 \\
\hline 45. & Recap the needle upto the moment of administration. & 47 & 94 & 2 & 4 & 1 & 2 \\
\hline 46. & Cleanse the skin with alcohol at $70 \%$ and allows it to dry. & 21 & 42 & 19 & 38 & 10 & 20 \\
\hline 47. & Pinch a fold of skin. & 41 & 82 & 1 & 2 & 8 & 16 \\
\hline 48. & Inject the needle at $45^{\circ} / 90^{\circ}$ angle. & 1 & 2 & 2 & 4 & 47 & 94 \\
\hline 49. & $\begin{array}{l}\text { Aspirate the fluid back into the syringe to check } \\
\text { for the blood return, if insulin syringe. }\end{array}$ & 2 & 4 & 2 & 4 & 5 & 10 \\
\hline 50. & Wait 5 second to withdraw the needle. & 39 & 78 & 4 & 8 & 7 & 14 \\
\hline 51. & Compress the skin without massaging it. & 33 & 66 & 5 & 10 & 12 & 24 \\
\hline 52. & Dispose the syringe after single use safely. & 50 & 100 & 0 & 0 & 0 & 0 \\
\hline 53. & $\begin{array}{l}\text { Do you have the habit of skipping/ adjusting the } \\
\text { without your doctor concern? }\end{array}$ & $\begin{array}{c}\text { dose } \\
50 \\
\end{array}$ & 100 & 0 & 0 & 0 & 0 \\
\hline 54. & $\begin{array}{l}\text { Regular examination of blood glucose level and } \\
\text { examination as adviced by doctor. }\end{array}$ & $\begin{array}{c}\text { eye } \\
50\end{array}$ & 100 & 0 & 0 & 0 & 0 \\
\hline 55. & $\begin{array}{l}\text { Do you have habit of doing exercise as advicee by } \\
\text { your doctor? }\end{array}$ & 22 & 44 & 20 & 40 & 8 & 16 \\
\hline
\end{tabular}


Table 7: Correlation between Knowledge \& Practice regarding Self Administration of Insu$\operatorname{lin}(\mathbf{n}=\mathbf{5 0})$

\begin{tabular}{|l|c|c|c|}
\hline & $\begin{array}{c}\text { Mean } \pm \\
\text { Sd. Deviation }\end{array}$ & $\begin{array}{c}\text { Correlation } \\
\text { value }\end{array}$ & P value \\
\hline $\begin{array}{l}\text { Knowledge } \\
\text { total score }\end{array}$ & $23.02 \pm 5.200$ & 0.28 & 0.049 \\
\hline $\begin{array}{l}\text { Practise_total } \\
\text { score }\end{array}$ & $29.54 \pm 3.072$ & & \\
\hline
\end{tabular}

\section{DISCUSSION}

A similar study was conducted by a Surendranath on October 2011 to assess the knowledge and practice of insulin self administration among patient with diabetic mellitus, knowledge assessment on self insulin administration revealed that 41 $(68 \%)$ of the subjects had inadequate knowledge; and remaining $19(32 \%)$ of them had moderately adequate knowledge. None of them had adequate knowledge. Assessment of the practice revealed that $43(72 \%)$ of the subjects had poor practice; $17(28 \%)$ of them had fair practice, and none of them had good practice. There was a statistically significant positive correlation between knowledge and practice on is a $(\mathrm{p}<0.05) 4$. In a study conducted by Hadegu Grensea et al 2015, the mean knowledge score of study subjects was 7.07 with a maximum possible score of 13 . Only $18(13.07 \%)$ of participants had good knowledge, $78(55 \%)$ participants had average knowledge and $45(31.8 \%)$ had poor knowledge regarding diabetes and insulin self administration ${ }^{5}$. In a similar study conducted by Manish C Gholap et al 2016, the mean knowledge score was $7.225 \pm 1.405$ and practice score was $6.000 \pm 1.519$. Out of 40 samples, $21(52.5 \%)$ were having good knowledge, 19(47.5\%) were having average knowledge; none of them were having poor knowledge. Out of 40 samples 1 (2.5\%) having poor practice, $33(82.5 \%)$ having average practice, and $6(15 \%)$ having good practices ${ }^{6}$. Our study revealed that mean knowledge of the participants was $57.55 \%$ and practice was $73.98 \%$. Among them 54\%(27) of participants has inadequate knowledge, remaining 46\% (23) has adequate knowledge. Similarly, $48 \%(24)$ of participants has inadequate practice, and remaining 52\%(26) has adequate practice. There was significant association of educational status with knowledge regarding self administration of insulin with pvalue 0.03 and there was significant association with occupation with knowledge regarding self administration of insulin with pvalue 0.047 . There was also association between knowledge and practice regarding self administration of insulin with pvalue 0.049 .

In our study, the majority $58 \%$ of the participants had studied upto primary level whereas in the similar study conducted by Manish C Gholap et al ${ }^{6} 2016$ majority $42.5 \%$ of the participants had attended primary education and in a similar study conducted by Hadgu Grensea et al5 majority $47.5 \%$ had attended primary education.

In our study majority $74 \%$ of the participants didn't had family history of DM whereas in a similar study conducted by Manish Gholap et al 2016, similar result i.e majority $80 \%$ of the participants \& $73.5 \%$ in a study conducted by Hadgu Grensae et al 2015 didn't had family history of $\mathrm{DM}^{5,6}$.

In our study majority $48 \%$ of the participants were under insulin therapy since 3 months -1 year whereas in a similar study conducted by Manish Gholap et al 2016, majority $50 \%$ of the participants were under insulin therapy for less than 1 year and $\%$ in a study conducted by Hadgu Grensae et al 2015, majority of the participants were under insulin therapy for 1-3 years ${ }^{5,6}$.

In our study majority $90 \%$ of the participant had knowledge that insulin should be stored in the refrigerator but only $50 \mathrm{~m} \%$ of the participants knew about the temperature to be maintained in refrigerator for the storage of insulin, only $6 \% /$ knew about the room temperature to be maintained for the storage of insulin and only $48 \%$ knew about the technique for storage of insulin incase the refrigerator is not available whereas in a study conducted by Hadgu Grensea et $\mathrm{al}^{5} 68.7 \%$ of the participants had knowledge that insulin should be stored in a refrigerator or cool \& dry place. 
In our study majority, $78 \%$ of the participants had appropriate knowledge regarding the time for insulin administration whereas in a similar study conducted by Hadgu Grensea et $\mathrm{al}^{5} .82 .9 \%$ of the participants had knowledge regarding time for administration of insulin.

In our study, among various sites abdomen (94\%) was most known sites of administration to the participants followed by thigh $(90 \%)$, upper arm (32\%) \& buttocks $(24 \%)$. In a study conducted by Hadgu Grensea et $\mathrm{al}^{5} 39 \%$ of the participants had knowledge about the sites of administration of insulin.

In our study, only $46 \%$ of the participants had knowledge on correct angle for the administration of insulin whereas in a similar study conducted by Hadgu Grensea et $\mathrm{al}^{5}$ only $16.3 \%$ of the participants had knowledge on correct angle for the administration of insulin.

In our study, $56 \%$ of the participants had knowledge regarding ways to control pain during ISA whereas the study conducted by Hadgu Grensea et $\mathrm{al}^{5}$ only $21 \%$ of the participants had knowledge regarding self administration of insulin.

In our study, among the various complication of insulin therapy low blood sugar (30\%) is the most known complication to the participants followed by lipodystrophy (16\%) \& insulin resistance/allergy (14\%), similarly in a study conducted by Hadgu Grensea et $\mathrm{al}^{5}$ only $10.14 \%$ of the participants had knowledge regarding complication of insulin therapy.

In our study only $42 \%$ of the participants always wipes the skin with alcohol whereas 38\% wipes sometimes only \& $20 \%$ never wipes the skin with alcohol before administration of insulin whereas in the study conducted by sarungbam et al $^{7}$ majority of patients $(72.42 \%)$ didn't clean the injection site.

In our study, only $22.22 \%$ of the participants withdraws syringe partly to check the blood, $22.22 \%$ of the participants withdraw the syringe sometimes $\& 55.55 \%$ of the participants never withdraw the syringe to check the blood during administration of insulin whereas in a similar study conducted by sarungbam et $\mathrm{al}^{7}$ none of them withdrew syringe partly to check for presence of blood.

In our study, only $6 \%$ of the participants always check their blood glucose level before the administration of insulin while $44 \%$ of them checks sometime and $50 \%$ never checks their blood glucose level before administration of insulin, similarly in a study conducted by various other authors none of them checked their blood glucose level before administration of insulin while majority of patients checked their blood sugar levels infrequently at 3-4 months interval ${ }^{8-10}$.

In our study, all the participants (100\%) didn't selfadjust dose of insulin without consulting physician whereas in a study conducted by sarungbam et al7 most of the patients $51(91.07 \%)$ didn't self-adjust dose of insulin without consulting physician.

\section{Conclusions}

knowledge and practice has a significant association with each other. Thus it is essential to focus on improving the patient's knowledge on the related topic so that the participants can enhance their practice as well. Diabetes \& Insulin Self Administration education must be imparted by physicians by counselling patients at each follow up visit while physicians, nurses \& other health care provider themselves should be enriched with more knowledge through $\mathrm{CME} / \mathrm{CNE}$ and other programmes. Other sources of information like articles, newspapers, television, NGOs (NonGovernment Organisations) can play vital role in imparting knowledge regarding diabetes and insulin use in the community. 


\section{REFERENCES}

1) http://www.who.int/campaigns/world-healthday/2016/event/en/

2) Smeltzer S C, Bare B G, Janice L et al. Brunner \& Suddarth's Textbook of Medical-Surgical Nursing. 11th edition. Lippincott Williams \& Wilkins. 2009. p1375-1410.

3) Choudhury SD, Das SK and Avijit Hazra. Survey of knowledge-attitude-practice concerning insulin use in adult diabetic patients in eastern India. 2014 JulyAugust; Vol46 (4)

4) Nath AS, Nagraju B, Padmavati GV, Balchandra G. A study to assess the knowledge and practice of insulin self-administration among patients with diabetes mellitus. 2012 Jan;[cited 2016 November 4 ]; Vol $5(1)$.

5) Gerensea H, Moges A, Shumiyee B, Abrha F, Yesuf M, Birihan T, Getahun Z. Knowledge and attitude on insulin self-administration among type one diabetic patients in Mekele hospital,Tigray, Ethiopia, 2015, Advances in Surgical Sciences. 2015 october 8; [cited 2016 december 5]; Vol 3(5):p32-36.

6) Gholap MC, Mohite VR, Chendake MB, Heremath P. A study to assess the knowledge and practices of selfadministration of injection insulin among diabetic patient attending out patient department of Krishna Hospital, Karad. 2016 September 17; [cited 2016 october 10]; Vol 6(9):p277-82.

7) Sarungbam SD.Effectiveness of structured teaching programme on self-administration of insulin in terms of knowledge and skill of patients with Diabetes Mellitus. 2015 July 27; Vol 1(9): p919-21.

8) Shettigar S, Kamath A, Alva GL, Latha T, Navil JR. Training on improving the competency level of self-administration of insulin among type II diabetes patients. 2013 september; Vol 3(3) .

9) Swapna M K. Effectiveness of structured teaching programme on knowledge and skills regarding the insulin self administration(ISA) among the Diabetes Mellitus patients in selected hospital of Delhi. 2016 February; Vol 4(2): p697-702.

10) Atalla HRA. Effectiveness of nursing intervention regarding self insulin administration among diabetic patients,Egypt. 2016 April 25; Vol 4(2): p57-66.

11) Stacciarini TSG, Pace AE, Hass VJ. Insulin selfadministration technique with disposable syringe among patients with diabetes mellitus followed by the family health strategy. 2009 July; Vol 7(6). 